\title{
Seed Shrimp, Mussel Shrimp (Freshwater Ostracods) scientific name: (Crustacea: Ostracoda: Podocopa) ${ }^{1}$
}

\author{
Carrie Suen and Jennifer L. Gillett-Kaufman²
}

\section{Introduction}

Ostracods are a class of small crustaceans that inhabit both saltwater, freshwater, and damp terrestrial environments. There are approximately 8,000 extant species of ostracods. Non-marine ostracods belong to the Order Podocopida, which is comprised of the superfamilies Cypridoidea, Darwinuloidea, and Cytheroidea (Thorp 2015). They are commonly known as seed shrimp due to their small size, typically smaller than a poppy seed or up to $1 \mathrm{~mm}$. Their carapace, the upper shell of crustaceans, is bivalved, giving it the common name mussel shrimp.

Cypridopsis vidua is a species of seed shrimp found in Florida that has a worldwide distribution; it is found in freshwater environments around the world. Members of this species feed on periphyton, which is a combination of algae, cyanobacteria, heterotrophic microbes (bacteria, yeast, and molds), and detritus (dead organic material) attached to aquatic vegetation, such as the green alga, Chara fragilis (Roca et al. 1993). The defensive techniques of Cypridopsis vidua are quite intriguing. When exposed to water from aquarium tanks that contained fish, Cypridopsis vidua was able to detect small chemical traces of the fish and retreat into hiding.

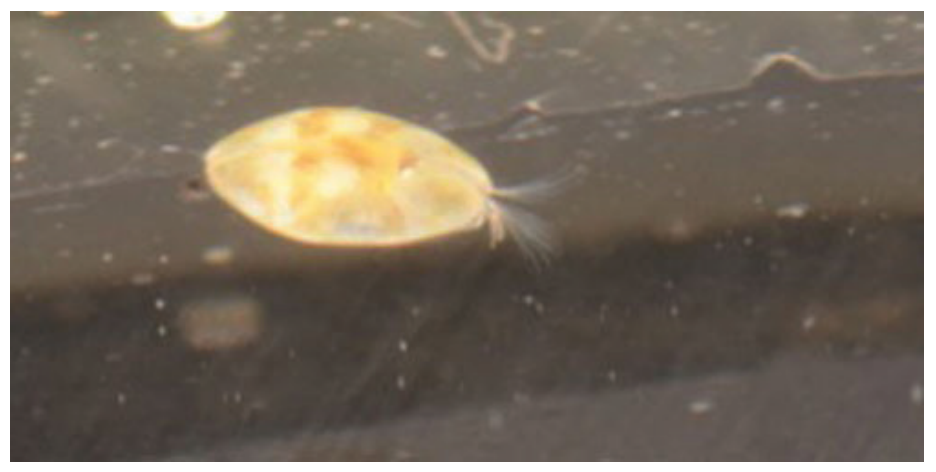

Figure 1. Top view of seed shrimp under a microscope, Cypridopsis vidua (Müller), with antenna visible on the right side. Crustaceans use their antennae to sense their surroundings.

Credits: Lyle J. Buss, UF/IFAS

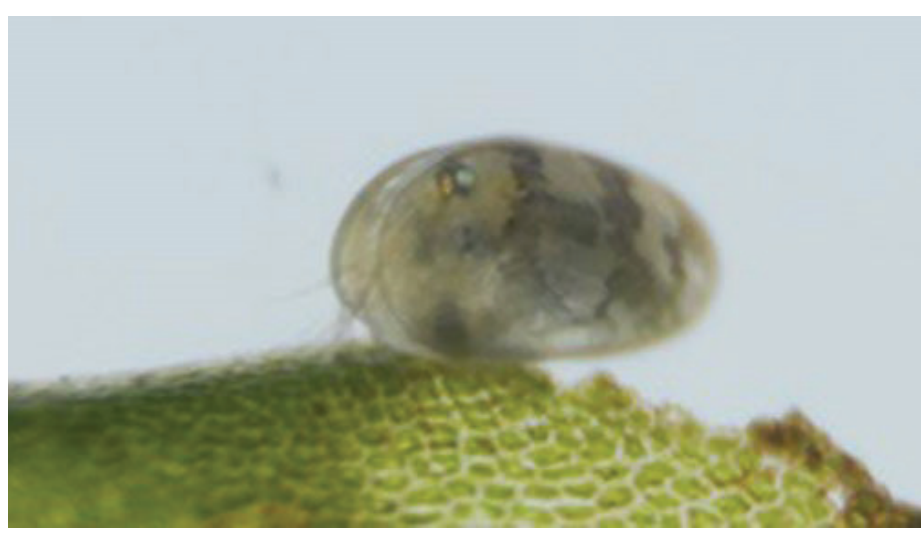

Figure 2. Side view of seed shrimp, Cypridopsis vidua (Müller) on a piece of Lomariopsis (Süsswassertang) with antenna visible at the left. Credits: Lyle J. Buss, UF/IFAS

1. This document is EENY-734, one of a series of the Entomology and Nematology Department, UF/IFAS Extension. Original publication date August 2019. Visit the EDIS website at https://edis.ifas.ufl.edu for the currently supported version of this publication. This document is also available on the Featured Creatures website at http://entomology.ifas.ufl.edu/creatures.

2. Carrie Suen; and Jennifer L. Gillett-Kaufman, associate Extension scientist; Entomology and Nematology Department, UF/IFAS Extension, Gainesville, FL 32611.

The Institute of Food and Agricultural Sciences (IFAS) is an Equal Opportunity Institution authorized to provide research, educational information and other services

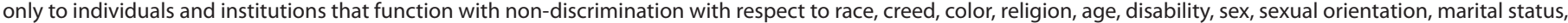

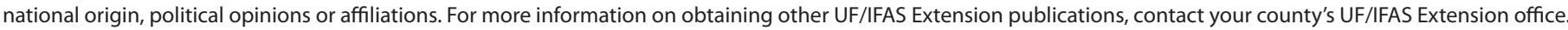
U.S. Department of Agriculture, UF/IFAS Extension Service, University of Florida, IFAS, Florida A \& M University Cooperative Extension Program, and Boards of County Commissioners Cooperating. Nick T. Place, dean for UF/IFAS Extension. 


\section{Distribution}

The Palearctic region contains the highest diversity of seed shrimp, followed by the Afrotropical and Australian regions. Freshwater seed shrimp can be found in lakes, wetlands, vernal (seasonal) pools, oxygenated groundwater, and streams, whereas other ostracods live in marine environments. One unusual species of semi-terrestrial Ostracoda lives in damp areas of leaf litter or on mosses near waterfalls (Martens et al. 2007).

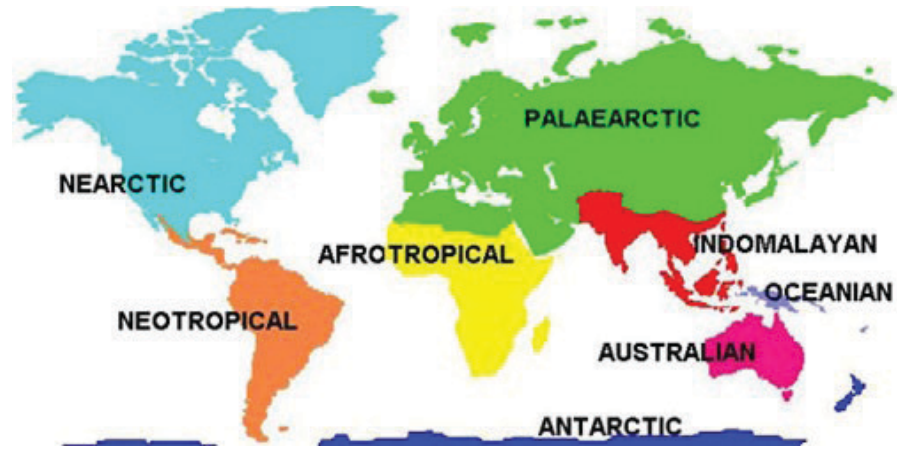

Figure 3. Map of biomes. Ostracods can be found virtually worldwide. Credits: Used with permission from Earth Online Media

\section{Description and Life Cycle}

Seed shrimp use a variety of methods for reproduction and can reproduce either sexually or asexually via parthenogenesis (Martens et al. 2007). Parthenogenesis allows for females to produce young without fertilization. Some species of seed shrimp lay their eggs on the surfaces of aquatic plants or in the water, whereas some species may brood their eggs internally and release living larvae after the eggs have hatched internally. Seed shrimp that inhabit vernal pools produce cysts that can survive dry periods; these cysts hatch once there is enough water. Cysts are eggs that are suspended in a membrane-bound fluid. This coating allows the eggs to survive extended dry periods.

The most common families of freshwater ostracods include Cyprididae, with 1,000 species, and Candonidae with 550 species (Martens et al. 2007). They inhabit benthic (floor) regions of water bodies and are found in periphytic communities. Organisms that are periphytic live on the surfaces of rooted aquatic vegetation.

To view the details of seed shrimp anatomy requires a microscope with at least 40x magnification. With the naked eye, the seed shrimp look like a dark swimming dot and are less than a millimeter in length, with few external identifying characteristics.

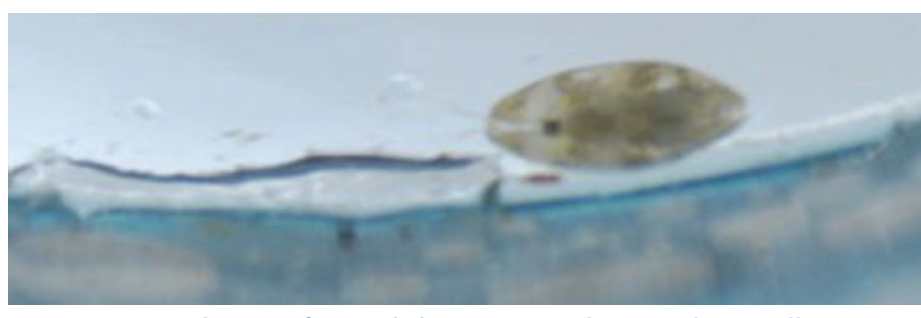

Figure 4. Dorsal view of a seed shrimp, Cypridopsis vidua (Müller). Credits: Lyle J. Buss, UF/IFAS

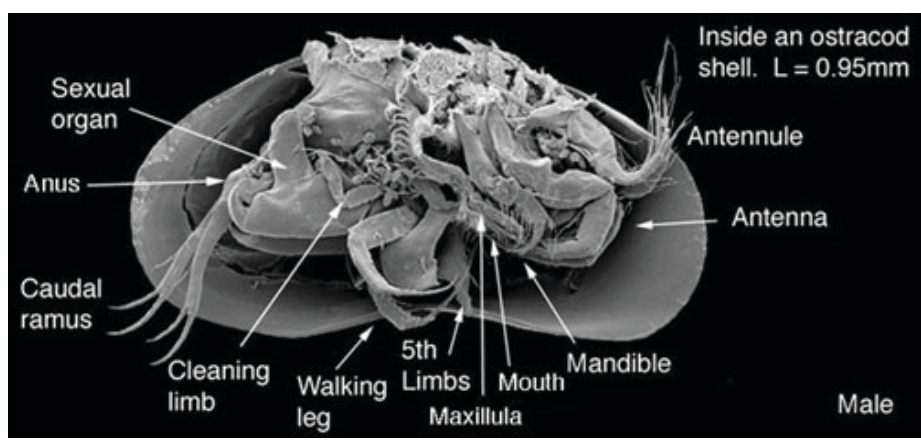

Figure 5. Cross section of a seed shrimp, Heterocypris incongruens (Ramdohr).

Credits: Robin J. Smith. Ostracod Research at the Lake Biwa Museum

\section{As a Host}

Non-marine ostracods are known to serve as a host for the endosymbiotic (lives internally in seed shrimp) bacteria Cardinium (Schön et al. 2018). Endosymbiotic bacteria live in a mutualistic relationship within other organisms. Cardinium bacteria are commonly found in the reproductive tissue of arthropods, mites, and spiders. Cardinium have been shown to cause feminization of the male host organism (Nakamura et al. 2009). Researchers recently discovered a new strain of Cardinium in all three superfamilies of non-marine ostracods through DNA sequencing. This strain of Cardinium found in the ostracods resembles those found in Diptera and Nematoda (flies and nematodes). Researchers have yet to observe horizontal transmission of this bacteria between ostracod and non-ostracod hosts (Schön et al. 2018).

\section{Selected References}

Martens K, Schön I, Meisch C, Horne DJ. 2008. "Global diversity of ostracods (Ostracoda, Crustacea) in freshwater." Hydrobiologia 595: 185-193.

Nakamura Y, Kawai S, Yukihiro F, Ito S, Gotoh T, Kisimoto R, Yanase T, Matsumoto Y, Kageyama D, Noda H. 2009. "Prevalence of Cardinium bacteria in planthoppers and spider mites and taxonomic revision of "Candidatus Cardinium hertigii" based on detection of a new Cardinium group from biting midges." Applied Environmental Microbiology 75 (21): 6757-6763. DOI: 10.1128/AEM.01583-09. 
Roca JR, Baltanas A, Uiblein F. 1993. “Adaptive responses in Cypridopsis vidua (Crustacea: Ostracoda) to food and shelter offered by a macrophyte (Chara fragilis)." Hydrobiologia 262: 127-131.

Schön I, Kamiya T, Berghe TV, Broecke LV, Martens K. 2018. "Novel Cardinium strains in non-marine ostracod (Crustacea) hosts from natural populations." Molecular Phylogenetics and Evolution 130: 406-415. DOI: 10.1016/j. ympev.2018.09.008.

Thorp JH, Rogers DC. 2015. Thorp and Covich's Freshwater Invertebrates. 4th Edition. Elsevier Science, New York, NY. pp. 470-486. 